\title{
1. Introduction to The Diffusion of Public and Private Sustainability Regulations: The Responses of Follower Countries
}

\section{Etsuyo Michida, John Humphrey and David Vogel}

This collection of chapters focuses on the spread of environmental and food safety regulations to Asia and Africa. One of the striking features of the global economy over the past 20-30 years has been the rapid spread of such regulations across jurisdictions. International treaties are one way in which regulations and policies can spread across countries, and in the environmental field initiatives such as the Montréal Protocol controlling emissions of chlorofluorocarbons (CFCs) and the Minamata Convention on Mercury (Meckling, 2018) have been promoted in this way. Nevertheless, much of the cross-national spread of environmental policies has taken place in the absence of such organized international action. Tews and Busch argue that "global convergence of environmental policy can take place in the absence of a strong international regime, within which states committed themselves to certain policies and which provides strong compliance mechanisms" (2001: 168).

The spread of policies through such mechanisms is called "policy diffusion." This has been defined as "the process by which policy innovations are communicated in the international system and adopted voluntarily by an increasing number of countries over time" (Busch, Jörgens and Tews, 2005: 149). The extensive literature in this field analyzes not only the spread of environmental policies, but also issues such as employment and welfare policies (Dolowitz and Marsh, 2000), the adoption of anti-smoking initiatives by US cities (Shipan and Volden, 2008), the global spread of controls over the production and use of chemicals (Biedenkopf, 2012; Michida, 2014), the adoption of performance management systems in Chinese cities (Liu and $\mathrm{Li}, 2016$ ) and the way in which European Union (EU) institutions and policies have been adopted in countries and regions far from the EU's immediate zone of influence (Börzel and Risse, 2012). This literature focuses on a range of policy diffusion issues, and two of 
these are particularly salient for the chapters in this volume. The first concerns the motivations for diffusion. What are the factors that induce authorities in one jurisdiction to adopt policies developed in another? The second is about policy convergence and divergence. Policies and policy ideas may spread (or diffuse), but the result is not necessarily the implementation of identical policies across locations (Gilardi, 2013). Domestic factors may influence how policies are implemented, and while policy principles may be adopted, the design and implementation of concrete policies may differ.

The chapters in this volume explore these issues but add to the literature in two ways. The first is geographical focus. While much of the existing literature has addressed policy diffusion among Northern countries that share similar norms, policy priorities and stages of development (Busch, Jörgens and Tews, 2005; Héritier, Knill and Mingers, 1996), this volume focuses on non-Western countries (both developed and developing) in their role as follower countries that adopt food safety, environmental and sustainability policies, but under conditions different to those of the originating country. Compared to the rich literatures on Europe and the United States, limited research has been undertaken in non-Western countries. Developing country cases, where they exist, are largely addressed as samples of a larger set of countries (Busch, Jörgens and Tews, 2005; Simmons and Elkins, 2004). Research focusing on the diffusion of European environmental policy to Asian developing countries (Biedenkopf, 2012; Michida, 2017) shows that the motivations for adopting regulations or standards developed in other jurisdictions and the extent of their divergence reflect a variety of local conditions, including a country's social and economic priorities, the capacity of the state to implement policy mechanisms, the interaction with existing laws and regulations, the capabilities of local producers and consumer preferences.

The second contribution of this volume lies in its attention to the role of non-state actors in the cross-national diffusion of policies relating to the environment and food safety. The literature on policy diffusion focuses predominantly on government-to-government policy spread. For example, Shipan and Volden characterize policy diffusion as "the spread of [policy] innovations from one government to another” (2008: 841). Simmons, Dobbin and Garrett also confine the discussion to government policy: "International policy diffusion occurs when government policy decisions in a given country are systematically conditioned by prior policy choices made in other countries" (2006: 787).

This focus on government policymaking has occurred at a time when a salient feature of transnational governance has been the rapid growth of non-state forms of transnational regulation. A large number of "private" transnational governance initiatives around the environment, sustainability and food safety have emerged since the 1990s, and it has been argued that 
"An increasing portion of business regulation emanates not from conventional state and interstate institutions, but from an array of private sector, civil society, multi-stakeholder and hybrid public-private institutions operating in a dynamic, transnational regulatory space" (Eberlein et al., 2014: 1). Initiatives include the Marine Stewardship Council and Forest Stewardship Council sustainability standards (Bush and Oosterveer, 2015; Dingwerth, 2008; Pattberg, 2005), Roundtables for the sustainable production of commodities such as soy, palm oil, sugar and biofuels (Hospes, 2014; Schouten and Glasbergen, 2011), and "green" building design (Schindler, 2010). These initiatives, which have been developed predominantly through the activities of multi-stakeholder coalitions led by businesses and non-governmental organizations (NGOs) from high-income countries, are designed to control the way in which products are made so that desirable impacts relating to food safety, social conditions and environmental consequences are achieved, or undesirable impacts eliminated or mitigated. These form part of the global diffusion of policies in this area. ${ }^{1}$

The next section of this Introduction develops a discussion of the diffusion of public and private regulations, paying particular attention to the relationship between the motivations for diffusion and the degree of convergence between regulations in the countries of origin and those in countries to which they have diffused. Section 1.2 then discusses the chapters in the volume and identifies their contributions to the discussion of the diffusion of public and private regulations. Section 1.3 concludes.

\subsection{POLICY DIFFUSION: MOTIVATIONS AND CONVERGENCE}

The literature on policy diffusion has highlighted four classes of mechanisms that might drive the diffusion of policies across countries: learning, emulation, competition and coercion (Gilardi, 2013; Shipan and Volden, 2008; Simmons and Elkins, 2004). ${ }^{2}$ These can be taken as a continuum that ranges from purely voluntary action to adopt a standard through to adoption as a result of an exercise of coercive power (Dolowitz and Marsh, 2000: 9), with diffusion often arising from a combination of these mechanisms. While the discussion of these factors has been confined to the adoption of public policies by public agencies, it will be argued that they also apply to the diffusion of private regulations.

Learning and emulation are at the voluntary end of the continuum. Learning refers to the process by which policy diffusion is prompted by the examination of the experiences of other countries (or jurisdictions) and the use of this knowledge to inform choices about policy adoption. One example of learning within Asia was the introduction across the region of bans on the import of waste plastic for recycling. This policy was first introduced in China at the end of 2017, but neighboring Asian countries subsequently introduced similar 
bans, partly because of learning from China, and partly in order to manage inflows of waste diverted to them following the change of Chinese policy. Transnational networks of policymakers often promote such learning and diffusion, as discussed in the case of municipal climate strategies in Europe (Hakelberg, 2014). Learning from the experience of others simplifies policy choices. It acts as an important mechanism for the development of local regulations by both government and business.

In the case of learning, the focus is on the policy being adopted. Emulation, in contrast, arises when the motivation for transfer is not the policy (or the action), but rather the characteristics of the actors that had previously adopted it (Shipan and Volden, 2008: 842-3). According to Biedenkopf, "Emulation is the mechanism by which policy makers adopt policy similar to that of another jurisdiction based on the belief that this policy is legitimate and appropriate" (2012: 481). While some analysts have emphasized the importance of geographical proximity in the operation of the emulation mechanism (Howlett, 2000), cases involving geographical distance have also been discussed. For example, it has been argued that the EU's development of its own institutions influenced the characteristics of the ASEAN Charter and the Andean Court of Justice through a process of emulation (Börzel and Risse, 2012: 2-3). As the diffusion of particular policies becomes more widespread, so the legitimacy and appropriateness of these policies becomes established. Countries may adopt policies because this shows that they are ready to work within a framework of widely accepted international rules. Both learning and emulation are associated with the voluntary adoption of policies developed in other jurisdictions.

The competition motivation relates to the way in which policies might spread because countries seek to maintain their competitiveness. This can lead to two types of diffusion. The first is across countries that occupy similar positions within the world economy. If one country adopts a policy that provides it with a competitive advantage (for example, a more favorable tax regime for foreign investors, or the provision of better infrastructure and support facilities) then other countries might adopt similar policies in order not to be disadvantaged as an investment location (Oman, 2000).

The second type of competition-driven diffusion occurs when policies are adopted in order to conform to public or private regulations required for access to destination markets. Such requirements are often introduced into preferential trade agreements, as discussed by Hafner-Burton (2005), who examines how such agreements can be used to change exporting country behavior in areas such as human rights and child labor. Similar market access conditionalities are used to promote the diffusion of environmental policies. This is seen clearly in the case of the EU's controls over the timber trade. The EU Timber Regulation requires companies placing timber on the EU 
market to establish that it has been harvested in accordance with the laws of the exporting country, and the EU provides guidance about how this might be done (European Commission, 2016). At the same time, Voluntary Partnership Agreements with timber-exporting countries redefine the definition of what counts as legally-harvested product and commit the partner countries to introduce controls not only over timber exported to the EU, but also that placed on the domestic market of the exporting country or exported to any other country (Humphrey, 2017: 33-7).

The use of market access as a lever to change policy in exporting countries can be implemented in different ways. One option is to require the exporting country to introduce domestic regulations that will regulate behavior to achieve the desired goals. The regulations do not have to be the same as those adopted in importing countries: it is merely necessary for new regulations to have an equivalent outcome in terms of the desired goals. Thus, the EU Food and Veterinary Office checks the food safety systems of countries exporting to the EU to verify that they have the capacity to regulate the food export businesses in ways that provide a level of assurance equivalent to that achieved by food safety systems within the EU (Humphrey, 2017). Where there are known and unresolved problems with imported products, additional border checks may be required on entry, or policy innovations required in the exporting country that will provide assurances about the acceptability of exported products. The negotiation between the EU and China about controls over aflatoxin contamination in Chinese groundnut exports would be an example (Diaz Rios and Jaffee, 2008: 19-20). Finally, governments in exporting countries may incorporate export market requirements into domestic law in order to create convergence between domestic and export market regulations and reduce the burdens placed on exporters. Export businesses, including multinational companies, may lobby governments to take such measures (Vogel, 1995).

However, as the consequences of non-adoption become more severe, so the motivating factor looks closer to coercion, as outlined by Dolowitz and Marsh (2000). The extreme case of coercion identified in the diffusion literature is where there is a direct and hierarchical exercise of coercive power by one government body over another. Liu and Li give the example of one level of government in China exerting direct control over the adoption of policies by another, subordinate level. They argue that this should not be considered a case of policy diffusion at all, with the result that they restrict diffusion mechanisms to competition, learning and imitation (Liu and Li, 2016: 633). Other authors take a different view, arguing that powerful actors in the global economy can influence policy in other countries and that this should be considered as diffusion through coercion. Drezner defines coercion as "the threat or act by a sender government or governments to disrupt economic exchange with the target state, unless the target acquiesces to an articulated demand" (2003: 
643). ${ }^{3}$ Dobbin, Simmons and Garrett provide examples of coercive diffusion driven by governments and international organizations:

Coercion can be exercised by governments, international organizations, and nongovernmental actors through physical force ... the manipulation of economic costs and benefits, and even the monopolization of information or expertise. Thus, the preferences of the U.S. government, the European Union (EU), the International Monetary Fund (IMF), and the World Bank may shape policy in countries reliant on those entities for trade, foreign direct investment, aid, grants, loans, or security. Some argue that coercion is not a mechanism of diffusion, in that policy change is not voluntary. We do not treat military force as a mechanism of policy diffusion, but we do review studies of persuasion, loan and aid conditionality, and unilateral policy choices that shape the choices of other countries. (Dobbin, Simmons and Garrett, 2007: 454)

Such coercion has been associated with what Vogel (1995) terms the "race-to-the-top." Regulatory adoption leads to upwards convergence of regulations.

These same diffusion mechanisms are visible in the spread of private regulation. The proliferation of private standards occurs, in part, as a result of learning and emulation. Standard-setting bodies learn from each other, both informally and through networks of standard-setting bodies, including the ISO and organizations such as the International Federation of Organic Agriculture Movements (IFOAM), the ISEAL Alliance, whose Board of Directors includes representatives from many private standard-setting organizations that develop and administer private standards (ISEAL Alliance, 2018: 10), and business groups such as the Consumer Goods Forum, which is responsible for the benchmarking of standards through the Global Food Safety Initiative.

The competition mechanism for the diffusion of policies aimed at regulating the behavior of businesses in supply chains is central to non-state, market-driven (NSMD) standards. Even without state authority, such private regulation is able to create positive and negative sanctions to shape behavior. Cashore refers to:

the emergence of domestic and transnational private governance systems that derive their policy-making authority not from the state, but from the manipulation of global markets and attention to customer preferences ... nongovernmental organizations (NGOs) have developed governance structures and social and environmentally focused rules concerning the production and sale of products and services. (Cashore, 2002: 503-4)

Prakash and Potoski provide a clear example of the effect of trade in promoting the diffusion of private regulation. They studied levels of certification for the ISO 14001 environmental management standard across a panel of 108 coun- 
tries over a seven-year period. ${ }^{4}$ The key finding is that levels of certification are not related to the overall trade exposure of a country (exports in relation to gross domestic product, GDP), but rather to the levels of certification in the countries to which the country is exporting:

Our results suggest that while high levels of trade per se may not significantly affect firms' decisions to adopt ISO 14001, trade can be a vehicle to disseminate ISO 14001 if the key export markets have widely adopted this nongovernmental regulation. Thus, importing countries are influencing organizational practices in the exporting countries, not vice-versa. (Prakash and Potoski, 2006: 359)

The case where exporting businesses find that certain customers make ISO 14001 certification an order-qualifying criterion is a clear example of the competition motivation. To the extent that exporters are free to target different customers and different markets or may find other ways of displaying their environmental credentials to potential customers, this is not coercion. However, the pressure to adopt standards may be very strong. For example, Kenya's exports of fresh vegetables have mostly been directed to the UK and Dutch markets, and exporters have invested in facilities that meet the specific requirements of these countries in terms of compliance to both public and private regulations and the provision of services such as food preparation and the use of customer-specific packaging. These represent upfront investments whose value would be considerably reduced if used for preparing exports to other countries or market niches (Humphrey, 2008). In such circumstances, businesses are under pressure to comply with the rules set out by the standard, although it is also possible for local variants of the standard, benchmarked to the transnational standard, to provide some local adaptation while offering equivalent outcomes.

The comparison between coercion-competition and learning-emulation factors creates an apparently simple contrast. If the adoption of regulations is driven by the desire to maintain access to particular export markets, equivalence must be maintained between what is adopted in the exporting country and the requirements of the destination market. Trading relations provide motivations for regulatory alignment. If, on the other hand, there are no direct trading relationships to drive alignment, countries are more likely to be motivated by learning and emulation and to adjust policy selection and policy implementation to a greater extent to meet the requirements of the domestic economy and existing regulatory frameworks.

The chapters in this volume that focus on trade-related standards (relating to food safety in fishing and palm oil standards) show that while strong trading links drive the diffusion of policy and the alignment of standards, the outcome is not always a strong policy alignment. Differences in priorities and capa- 
bilities may make it difficult to achieve full alignment. Equally, the chapters that focus on regulations not directly relating to trade (building standards, energy efficiency and emissions trading schemes) demonstrate how, even in the absence of trading relationships, pressure for standards alignment may exist. In particular, new standards created through learning and emulation may face design and implementation constraints arising from the need to interact with standards in other jurisdictions. These points are developed further in the discussion of each of the chapters.

\subsection{CHAPTER CONTENTS AND FINDINGS}

The clearest example of a strong association between trade linkages and regulatory alignment is found in Chapter 4 by Yanai on fisheries policies in Tanzania, Madagascar and Mauritius. It focuses specifically on the issue of food safety regulations and discusses the role of the competition and coercion mechanisms for diffusion through an analysis of how these countries responded to the regulatory framework implemented in one significant export market, the EU. The chapter outlines the particular stringency of EU regulations as they apply to food of animal origin and provides an account of how the EU monitors exporting country compliance to its regulations by means of audits that cover legislation, the activities of the competent authorities for food safety and the implementation of controls by food business operators. It then examines how the three exporting countries responded to the EU food hygiene regulations introduced in 2004 . While all three countries changed their laws and regulations in response to the new hygiene regulations, the chapter argues that the speed of response varied across the three countries and that Tanzania was noticeably slower in introducing changes than either Madagascar or Mauritius.

The chapter provides two explanations for this difference. The first relates to the importance of the EU fish products market for the three economies. The more important the market, the greater the pressure for compliance and the diffusion of regulatory policies from Europe to the exporting countries. In other words, different countries lie at different points along the continuum from competition to coercion. It is argued that the determining factor is not solely the share of the EU market in a country's total exports of fish and fish products, but rather relates to the importance of fish production and export for the economy as a whole. While the EU only accounts for one third of fish exports from Mauritius, the fishing industry as a whole is much more significant for Mauritius than for the other two countries, and this drives harmonization. In addition to this, the chapter points to the consequences for each of the three countries of their position within Regional Economic Communities in Africa. In this respect, Tanzania's membership of the East African Community is 
particularly relevant, because this grouping has advanced further than other regional groupings in terms of harmonization of standards, including for fish. This means that the process of revising regulations in response to the requirements of the EU market involves regional agreements and consent, which reduces the speed of responses to changes in EU regulations.

Chapter 2 by Humphrey and Michida examines the drivers of the development of national standards for sustainable palm oil in Indonesia and Malaysia. Prior to the introduction of the Indonesia Sustainable Palm Oil (ISPO) and Malaysian Sustainable Palm Oil (MSPO) standards, the main certification scheme for establishing the sustainability of palm oil production was the Roundtable on Sustainable Palm Oil (RSPO). This is an NSMD standard developed by a multi-stakeholder coalition that is accepted widely in Europe (by public authorities and businesses) as a key indicator of sustainability. Indonesia and Malaysia are the world's largest palm oil producers and are responsible for $90 \%$ of global exports, and the decision to create national standards that diverge from the RSPO standard-particularly in the areas of Free, Prior and Informed Consent and the protection of land with High Conservation Values - has been interpreted in much of the literature as an attempt to construct rivals to the RSPO that are designed to weaken environmental and community protections and prioritize producer interests and economic growth. In other words, national governments are trying to change the premises of the debate on sustainability.

Chapter 2 challenges this view. It shows that the declining importance of Europe as a destination market compared to the rapidly growing demand for palm oil in Asia opens up the possibility of creating alternative standards that might be acceptable in these newer markets. However, evidence is provided to show that the largest destination markets in Asia have very weak demand for certified sustainable palm oil of any type. In this context, it is argued that the drivers of the two national standards have become largely domestic, rather than linked to export markets. In particular, the two distinctive characteristics of these national standards - they have become mandatory for all producers, and thus extended to include smallholder farmers - not only significantly extend their scope as drivers of sustainability, given the importance of small farmer palm oil production in both countries, but also transform the standards into drivers of rural transformation. To be implemented effectively, they require extensive programs of rural development, smallholder capability-building and the development of group certification schemes. Accordingly, ambitious programs have been introduced in both countries to certify all smallholder farmer production. However, the chapter casts doubt on the ability of governments in both countries, and particularly in Indonesia, with respect to both the ability to transform smallholder farmer production and the capacity of the schemes 
to monitor and enforce the rules they set down. In both cases, it is too early to judge their success.

Chapters 2 and 4 are both concerned with trade-related standards. The other three chapters focus on standards developed primarily for the domestic market that are diffused through the learning and emulation mechanisms. Chapter 3 by Shiraishi and Iseda focuses on the adoption of standards aimed at reducing the environmental impact of the construction and operation of buildings (green building standards). The building sector is one of the largest contributors to greenhouse gas (GHG) emissions and primary energy consumption, and developing standards for economically, environmentally and socially sustainable buildings is increasing across the world. In this field, there has been a proliferation of local standards, with the chapter identifying 21 different standards developed across 26 countries.

The core questions of this chapter are first, whether it is cost-effective to create green building rating systems that respond to the specific conditions in a particular country in the context of a globalized market economy; and second, the relationship between domestic and global rating systems. These issues are explored through a quantitative analysis of levels of certification to Leadership in Energy and Environmental Design (LEED), the dominant global green building standard, and how levels of LEED certification are affected by the development of domestic green building standards. More in-depth analysis of interactions between standards is provided through an analysis of three green building standards: the Building Research Establishment Environmental Assessment Method (BREEAM), developed in the UK; the Comprehensive Assessment System for Building Environmental Efficiency (CASBEE) standard developed in Japan; and the Australian Green Star standard. The development of domestic systems facilitates take-up because they can be designed to be better suited to domestic conditions and domestic regulatory frameworks.

The quantitative analysis shows that, overall, the development of alternative local standards for green construction within a given country reduces the number of companies certified to LEED. More detailed examination of the relationship between LEED and the national standards developed in Australia, Japan and the UK shows that while the national standards in Japan and Australia have a statistically significant negative impact on levels of LEED certification in the two countries, the same does not apply for the UK. This is explained by a stronger convergence between the UK standard and LEED, which has a higher level of uptake in the UK. It is argued that while the development of local systems facilitates take-up because of their better fit with local needs, there is a resulting trade-off because local adaptation increases the divergences between the local standards and the globally accepted standard, and this drives up costs and makes local businesses that use them less competitive in global markets. The greater the convergence between the global and 
local standards, the easier it is for businesses to acquire certification to both standards and be able to expand into global markets.

Chapter 5 by Cheng examines emission trading schemes (ETSs) for GHGs in China, Korea and Japan. ETSs have been adopted across many countries and emulation and imitation are the main drivers of diffusion. Carbon market policy instruments cannot be simply copied from one jurisdiction to another, and as a result many ETSs have been modified to fit location-specific political, economic, social and institutional contexts. This creates considerable difficulties in integrating ETS markets, and yet in spite of this countries continue to engage in dialogue about ETSs and continue to search for common carbon pricing mechanisms. This leads to the core question of this chapter, "What motivates East Asian countries to continue multilateral conversations and to cooperate by sharing each other's experiences in spite of the difficulties in integrating different ETS systems?"

As has been seen in other chapters, policy diffusion does not necessarily mean "copying" or "policy convergence." In the case of ETSs, regulations are altered to meet the needs of diverse stakeholders and a range of local conditions. It is evident that in the three countries a considerable amount of experimentation and learning has taken place in the process of introducing ETSs. The three countries all engaged in a phased introduction process, with schemes introduced in phases or a succession of schemes introduced as local learning increased. Alongside "diffusion through learning" there was also a process of "learning after diffusion." This allowed experience to be accumulated and implementation problems and market failures to be addressed, but at the expense of increasing incompatibility between national schemes. These vary with respect to emission reduction targets, the range of sectors covered, their compliance mechanisms and the types of gases that they cover. As a result, it becomes very hard for emissions credits to be traded across national borders, or between ETSs.

In spite of these differences and non-compatibilities, cooperation between schemes continues. One reason for this is that the schemes can learn from each other, creating trust and preparing the ground for possible future cooperation. Such learning can improve schemes in general, and also enable countries to learn how to improve their specific domestic systems. A second reason is that many organizations and policy communities, both regional and global, facilitate exchanges with a view to promoting cooperation. The chapter provides a detailed analysis of the different activities and policy communities that support these knowledge exchanges. Nevertheless, these activities are more focused on improving each national system than creating the conditions for ETS integration. This case illustrates both the difficulties of linking different domestic initiatives once local conditions and local learning have led 
to differentiation between them, while at the same time showing that there is continuing interaction and learning between the schemes.

Chapter 6 by Kojima examines energy efficiency policy in Asia. Studies of policy diffusion have examined the factors that lead to policy divergence in the process of policy diffusion. This is often explained by reference to the specificity of domestic forces and domestic capabilities. This chapter notes a considerable heterogeneity in the timing and content of energy efficiency policy programs across 11 Asian countries. It then analyses some of the factors leading to the observed differences in timing and content, paying particular attention to the role of energy intensity and energy self-sufficiency in shaping policies in the period up to the beginning of the 21 st century. It adds to this, however, by introducing a temporal dimension, stressing how the motivations behind the adoption of energy efficiency policies have changed over time from responding to higher energy prices to recognizing the imperative of reducing GHG emissions.

The early adopters of energy efficiency policies in Asia were motivated by oil price rises, but their responses varied according to their energy intensity and energy self-reliance. Energy intensive economies have a greater incentive to introduce energy efficiency policies, while countries that are more self-sufficient in energy have fewer incentives to do so. These factors explain some of the differentiation in policy responses at this time. By the 1990s, however, GHG emissions and mitigation efforts were a much more significant driver of energy efficiency policies. At this time, countries that were relatively energy sufficient were still laggards, but after 2005 there was a much more general adoption of energy efficiency policies, with even energy-rich countries enacting energy efficiency regulations.

\subsection{CONCLUSIONS}

This volume examines five cases of the diffusion of public and private regulations. These confirm that trade-related motivations are one driving force for regulatory transfer. The continuing importance of the RSPO for access to the European market (Chapter 2) and the impact of EU regulations on fisheries policy in Africa (Chapter 4) highlight the continuing importance of competition as a mechanism for policy diffusion that operates across both public and private regulation. Exporting countries have to take into account the regulatory environment in destination markets, but they do not necessarily respond passively to these challenges. The case of national palm oil standards shows that the shifting balance of power in the global economy opens up new opportunities. Demand from non-Western countries, which grew rapidly in the first two decades of the 21st century, has changed some of the power dynamics around public and private regulation. At the same time, countries 
such as Malaysia and Indonesia (and Brazil) have become more confident about creating standards rather than passively accepting existing regulatory frameworks. The growth of nationalist sentiment in the global economy may reinforce this tendency. The two cases also show that responses to public and private regulations in destination markets may be shaped by domestic factors, and this was particularly evident in the case of the national palm oil standards in Indonesia and Malaysia.

The cases of green building standards, ETSs and energy efficiency policies fall in the terrain of learning and emulation as diffusion mechanisms. These are not related to trade, although there may be trade-related impacts, as would be the case with respect to international trade in building design and services. In this case, the studies show that the process of diffusion is far from limited to the introduction of policies developed in other jurisdictions with some greater or lesser degree of adaptation to local conditions. In all three cases, there is a considerable degree of interaction between national policies and the extra-national environment. The ETS case study shows ongoing interactions between different adopters and learning across jurisdictions, allowing experimentation that had the potentially unintended consequence of hampering cross-national integration. The green building case study points to the proliferation of green building standards and their adaptation to local circumstances, but also to the downside of divergence. In the case of energy efficiency policies, different motivations and different drivers of change led to a heterogeneous landscaper policy diffusion across Asia.

Global integration drives policy diffusion, trade-related regulations are powerful drivers of policy diffusion through the mechanisms of competition and coercion, and the increasing integration of the global economy facilitates emulation and learning. Public and private policies and regulations have spread across countries, and the trend is likely to continue. Nevertheless, the global economy is itself changing with the growth of emerging economies and the rise of nationalist sentiment in some developed and emerging economies. Follower countries may become more proactive and innovative in their responses to regulatory environments, but the studies in this collection show that there are a variety of ways in which choices and consequences are shaped by the external environment, and further work is required on how countries respond to the new challenges that they face, the resources they have available to do this and the linkages and interactions that both facilitate and constrain their actions. 


\section{NOTES}

1. These non-state governance forms have been referred to variously as private standards, non-state market-driven standards (Cashore et al., 2007), civil regulation (Vogel, 2010; Zadek and Forstater, 1999), private regulation (Cafaggi, 2010) and private law (van der Meulen, 2011). This chapter uses the terms private regulation and public regulation to distinguish between state and non-state governance mechanisms.

2. Sometimes "imitation" rather than "emulation" is presented as the fourth category (for example, Hakelberg, 2014; Shipan and Volden, 2008), but the mechanisms described are much the same.

3. Cited by Hafner-Burton (2005: 599).

4. The International Organisation for Standardization (ISO) is described by Prakash and Potoski as a non-state body because its members are "private sector national bodies," such as the American National Standards Institute and the Deutsches Institut für Normung (Prakash and Potoski, 2006: 352).

\section{REFERENCES}

Biedenkopf, K. (2012). Hazardous substances in electronics: The effect of European Union risk regulation on China. European Journal of Risk Regulation 3(4), 477-88, doi 10.1017/S1867299X00002415.

Börzel, T.A. and Risse, T. (2012). From Europeanisation to diffusion: Introduction. West European Politics 35(1), 1-19, doi 10.1080/01402382.2012.631310.

Busch, P.-O., Jörgens, H. and Tews, K. (2005). The global diffusion of regulatory instruments: The making of a new international environmental regime. Annals of the American Academy of Political and Social Science 598(1), 146-67, doi $10.1177 / 0002716204272355$.

Bush, S.R. and Oosterveer, P. (2015). Vertically differentiating environmental standards: The case of the Marine Stewardship Council. Sustainability 7, 1861-83, doi $10.3390 /$ su7021861.

Cafaggi, F. (2010). Private regulation, supply chain and contractual networks. Paper presented at the VIII Annual Conference of the Euro-Latin Study Network on Integration and Trade, Paris, October.

Cashore, B. (2002). Legitimacy and the privatization of environmental governance: How non-state market-driven (NSMD) governance systems gain rule-making authority. Governance: An International Journal of Policy, Administration, and Institutions 15(4), 503-29, doi 10.1111/1468-0491.00199.

Cashore, B., Auld, G., Bernstein, S. and McDermott, C. (2007). Can non-state governance "ratchet up" global environmental standards? Lessons from the forest sector. Review of European Comparative \& International Environmental Law 16(2), 158-72, doi 10.1111/j.1467-9388.2007.00560.x.

Diaz Rios, L. and Jaffee, S. (2008). Barrier, catalyst, or distraction? Standards, competitiveness, and Africa's groundnut exports to Europe. Agricultural and Rural Development Discussion Paper, 39. Washington, DC: World Bank. Retrieved from http://siteresources.worldbank.org/INTARD/Resources/Making_the_Grade_ePDF2 .pdf (last accessed July 2018).

Dingwerth, K. (2008). North-South parity in global governance: The affirmative procedures of the Forest Stewardship Council. Global Governance 14(1), 53-71. 
Dobbin, F., Simmons, B. and Garrett, G. (2007). The global diffusion of public policies: Social construction, coercion, competition, or learning? Annual Review of Sociology 33, 449-72, doi 10.1146/annurev.soc.33.090106.142507.

Dolowitz, D.P. and Marsh, D. (2000). Learning from abroad: The role of policy transfer in contemporary policy-making. Governance: An International Journal of Policy, Administration, and Institutions 13(1), 5-23, doi 10.1111/0952-1895.00121.

Drezner, D.W. (2003). The hidden hand of economic coercion. International Organization 57(3), 643-59, doi 10.1017/S0020818303573052.

Eberlein, G.B., Abbott, K., Black, J., Meidinger, E. and Wood, S. (2014). Transnational business governance interactions: Conceptualization and framework for analysis. Regulation \& Governance 8(1), 1-21, doi 10.1111/rego.12030.

European Commission (2016). Guidance document for the EU timber regulation. Commission Notice of 12.2.2016. C(2016) 755 final. Retrieved from https://www.agriculture.gov.ie/media/migration/forestry/eutr/EUTRCommi ssionGuidanceFeb2016160216.pdf (last accessed April 2014).

Gilardi, F. (2013). Transnational diffusion: Norms, ideas, and policies. In W. Carlsnaes, T. Risse and B.A. Simmons (eds), Handbook of International Relations. London: Sage, pp. 453-77.

Hafner-Burton, E.M. (2005). Trading human rights: How preferential trade agreements influence government repression. International Organization 59(3), 593-629.

Hakelberg, L. (2014). Governance by diffusion: Transnational municipal networks and the spread of local climate strategies in Europe. Global Environmental Politics 14(1), 107-29, doi 10.1162/GLEP_a_00216.

Héritier, A., Knill, C. and Mingers, S. (1996). Ringing the Changes in Europe: Regulatory Competition and the Transformation of the State. Britain, France, Germany. Berlin and New York: Walter de Gruyter.

Hospes, O. (2014). Marking the success or end of global multi-stakeholder governance? The rise of national sustainability standards in Indonesia and Brazil for palm oil and soy. Agriculture and Human Values 31(3), 425-37, doi 10.1007/ s10460-014-9511-9.

Howlett, M. (2000). Beyond legalism? Policy ideas, implementation styles and emulation-based convergence in Canadian and US environmental policy. Journal of Public Policy 20(3), 305-29, doi 10.1017/S0143814X00000866.

Humphrey, J. (2008). Private standards, small farmers and donor policy: EUREPGAP in Kenya. IDS Working Paper, 308. Brighton: Institute of Development Studies. Retrieved from http://www.ids.ac.uk/files/Wp308.pdf (last accessed June 2018).

Humphrey, J. (2017). Regulation, standards, and risk management in the context of globalisation. In E. Michida, J. Humphrey and K. Nabeshima (eds), Regulations and International Trade: New Sustainability Challenges for East Asia. Basingstoke: Palgrave Macmillan, pp. 21-58.

ISEAL Alliance (2018). Understanding certified small producers' needs. London: ISEAL Alliance. Retrieved from https:/www.isealalliance.org/sites/default/files/ resource/2018-07/ISEAL_Producer_Needs_Report_2018_0.pdf (last accessed January 2020).

Liu, W. and Li, W. (2016). Divergence and convergence in the diffusion of performance management in China. Public Performance \& Management Review 39(3), 630-54, doi 10.1080/15309576.2015.1138060.

Meckling, J. (2018). The developmental state in global regulation: Economic change and climate policy. European Journal of International Relations 24(1), 58-81, doi $10.1177 / 1354066117700966$. 
Michida, E. (2014). The policy impact of product-related environmental regulations in Asia. IDE Discussion Paper, 451. Chiba: Institute of Developing Economies.

Michida, E. (2017). Regulatory diffusion from Europe to Asia. In E. Michida, J. Humphrey and K. Nabeshima (eds), Regulations and International Trade: New Sustainability Challenges for East Asia. Basingstoke: Palgrave Macmillan, pp. 59-84.

Oman, C. (2000). Policy competition for foreign direct investment: A study of competition among governments to attract FDI. Development Centre Studies. Paris: OECD Development Centre. Retrieved from http://www.oecd.org/mena/competitiveness/ 35275189.pdf (last accessed January 2020).

Pattberg, P. (2005). The Forest Stewardship Council: Risk and potential of private forest governance. The Journal of Environment and Development 14, 356-74.

Prakash, A. and Potoski, M. (2006). Racing to the bottom? Trade, environmental governance, and ISO 14001. American Journal of Political Sciences 50(2), 350-64.

Schindler, S.B. (2010). Following industry's LEED: Municipal adoption of private green building standards. Florida Law Review 62(2), 285-350.

Schouten, G. and Glasbergen, P. (2011). Creating legitimacy in global private governance: The case of the Roundtable on Sustainable Palm Oil. Ecological Economics 70(11), 1891-99, doi 10.1016/j.ecolecon.2011.03.012.

Shipan, C.R. and Volden, C. (2008). The mechanisms of policy diffusion. American Journal of Political Sciences 52(4), 840-57.

Simmons, B.A. and Elkins, Z. (2004). The globalization of liberalization: Policy diffusion in the international political economy. American Political Science Review 98(1), 171-89.

Simmons, B.A., Dobbin, F. and Garrett, G. (2006). Introduction: The international diffusion of liberalism. International Organisation 60(4), 781-810, doi 10.1017/ S0020818306060267.

Tews, K. and Busch, P.-O. (2001). Governance by diffusion? Potentials and restrictions of environmental policy diffusion. In F. Biermann, R. Brohm and K. Dingwerth (eds), Berlin Conference on the Human Dimensions of Global Environmental Change. Berlin: Potsdam Institute for Climate Impact Research (PIK), pp. 168-82.

van der Meulen, B. (2011). Private food law: The emergence of a concept. In B. van der Meulen (ed.), Private Food Law. Wageningen: Wageningen Academic Publishers, pp. 29-50.

Vogel, D. (1995). Trading Up: Consumer and Environmental Regulation in a Global Economy. Cambridge MA: MIT Press.

Vogel, D. (2010). The private regulation of global corporate conduct: Achievements and limitations. Business \& Society 49(1), 68-87, doi 10.1177/0007650309343407.

Zadek, S. and Forstater, M. (1999). Making civil regulation work. In M.K. Addo (ed.), Human Rights and the Responsibilities of Transnational Corporations. The Hague: Kluwer Law International, pp. 69-76. 